\title{
Characterisation of Smallholder Irrigation Schemes in Chirumanzu District, Zimbabwe
}

\author{
Norman Mupaso ${ }^{1}$, Charles Nyamutowa ${ }^{1}$, Stein Masunda ${ }^{1}$, Nyasha Chipunza $^{1} \&$ Douglas Mugabe ${ }^{1}$ \\ ${ }^{1}$ Department of Agricultural Economics and Development, Midlands State University, Gweru, Zimbabwe \\ Correspondence: Norman Mupaso, Department of Agricultural Economics and Development, Midlands State \\ University, Gweru, PO Bag 9055, Zimbabwe. Tel: 263-773-722-324. E-mail: mupason@msu.ac.zw
}

\author{
Received: December 12, 2013 Accepted: December 25, 2013 Online Published: January 15, 2014 \\ doi:10.5539/jas.v6n2p189 URL: http://dx.doi.org/10.5539/jas.v6n2p189
}

\begin{abstract}
The study was conducted in 2011 at Hamamavhaire and Mhende irrigation schemes in Chirumanzu district in Zimbabwe to determine the typology of the farmers using different irrigation technologies. A structured household survey was carried out on a sample of 79 respondents drawn from farmers using the sprinkler $(n=32)$, flood $(n=39)$ and drip $(\mathrm{n}=8)$ irrigation systems. The information gathered was analysed and interpreted using descriptive statistics and inferential statistics in the form of the chi-square test and Analysis of Variance (ANOVA). The main findings showed that there are significant differences $(\mathrm{P}<0.05)$ in yield per hectare (for green maize, maize-grain, wheat and sugar-beans) across the three irrigation systems. Farmers using sprinkler irrigation were found to be better-off in terms of livestock ownership and household assets compared to those using drip and flood irrigation. The study recommended that there is need to provide agricultural training to farmers in irrigation schemes to enhance their productivity.
\end{abstract}

Keywords: smallholder, irrigation technology, characterisation, Zimbabwe

\section{Introduction}

Zimbabwe is a sub-tropical country with one rainy season per annum. The rainfall is erratic, unreliable and insufficient as only $37 \%$ of the country receives adequate rainfall for sustainable agriculture (Makombe \& Sampath, 1998). Trends over the years have shown that the majority of the country's wet seasons are often punctuated by mid-season droughts which affect crops resulting in poor harvests (Gumbo, 2006). About $70 \%$ of the smallholder farmers in Zimbabwe live in the semi-arid regions IV and V which are characterized by rainfall less than $600 \mathrm{~mm} /$ annum (Nhundu, Gwata, \& Mushunje, 2010). Hence, irrigated agriculture is a necessary though not sufficient condition to foster rural development and enhance the livelihoods of the rural poor farmers all year round.

There are several factors to consider before selecting a particular irrigation system. These include water source, topography, soils, climate, type of crops to be grown, availability and cost of capital and labour. It is also important to assess the appropriateness of a particular irrigation technology to farmers and its associated energy requirements, water use efficiencies as well as socio-economic, health and environmental aspects (Food and Agriculture Organisation [FAO], 1999). It is not wise however to use a single criterion for selection purposes. However, there are instances when one criterion can weigh heavily in favour of a particular irrigation system. For example, the socio-economic impact of an irrigation system largely determines the success and sustainability of the project (FAO, 1999). This embraces the socio-economic costs and benefits that can be derived, not only by the government but also by the communities in which the project is located and how these affect the sustainability of the project (Ibid). This is because in any farming system the farmer is the central player and a viable system is one that improves the farmer's livelihood as well as the community's welfare at large. If the socio-economic benefits heavily out-weigh the costs then there are good chances that the irrigation intervention will be sustainable.

According to the FAO (1999), health and environmental aspects are also vital. The introduction of irrigation in a particular farming system brings in both positive and negative aspects to the system. For example, irrigation on one hand can improve the health of farmers as they will have access to a balanced diet (as various crops will be grown) and can afford medical services. On the other hand, it can introduce health hazards such as malaria (plasmodium falciparum) and bilharzia (schistosomiasis) if mitigatory measures are not adequately addressed. Hence, it is important to factor-in these issues during the irrigation scheme design, implementation, operation and 
management. Irrigation development may also introduce other environmental risks such as salinization, soil erosion and the deterioration of biodiversity. Consequently, it is essential to obtain all the available information and data and carry out an analysis of all the factors before ranking the criteria for purposes of selecting an irrigation system.

In order for a project to be sustainable all the technical, socio-economic, health and environmental information should be analyzed in such a way that the system chosen is technically feasible, economically viable, socially acceptable and environmentally sound. For the selection criteria, not only should the technical aspects of the system be considered, that is aspects such as access to reliable water sources, a secure and well-fenced garden, basic gardening skills and the crops grown. The social aspects should also be of concern to ensure the irrigation system will be of benefit to the community. The social and economic factors include capital and financial management, credit facilities, the availability of external services, maintenance, market opportunities for the produce and willingness to show other farmers the technology (Savva \& Frenken, 2002).

The aim of this study was to determine the characteristics of smallholder communal farmers using different irrigation technologies in Chirumanzu district, Zimbabwe. The information generated from the study is important for guiding future research, irrigation development and the rehabilitation of smallholder communal irrigation schemes in Zimbabwe.

\section{Research Methods}

\subsection{The Study Area}

The study was conducted at Hamamavhaire (Note 1) and Mhende (Note 2) irrigation schemes which are located in Chirumanzu district in the Midlands province of Zimbabwe. The district was purposively chosen as it incorporate both agro-ecological regions III and IV, which receive erratic rainfall (400 $\mathrm{mm}$ to $510 \mathrm{~mm}$ per annum) and temperatures range from $24^{\circ} \mathrm{C}$ to $31^{\circ} \mathrm{C}$ (Gumbo, 2006). Thus, irrigated agriculture plays a significant role in terms of any meaningful crop production. The soils in the area are mainly from the granite parent material and are inherently infertile.

The sprinkler (103 hectares) and drip (10 hectares) sections at Hamamavhaire irrigation scheme were commissioned in 1972 and 2001 respectively. The sections have separate pumping units and both draw water from Hamamavhaire dam. The average plot size is 1 ha under both sections. There are 103 farmers using sprinkler irrigation and 10 farmers use drip irrigation. The major crops grown in both sections are maize, wheat and sugar beans.

Mhende irrigation scheme was commissioned in 1972. It covers an area of 80ha with 304 beneficiaries. Each farmer holds at least a 0.1 ha plot. Water is drawn from Mhende dam and it flows by gravity from the dam to the field via a canal. The farmers mainly grow maize, wheat and sugar beans, with horticultural crops grown for subsistence.

\subsection{Sampling}

The study unit for the research was at household level. The area of study and irrigation schemes was chosen purposively to target an area receiving low rainfall and has farmers using different irrigation technologies. A sample of 79 respondents was randomly selected from the irrigation schemes and interviewed. The composition of the respondents was as follows: 32 using sprinkler irrigation, 39 using flood irrigation and eight using drip irrigation.

\subsection{Data Collection, Analysis and Presentation}

The study used both qualitative and quantitative data. Primary data were collected using a structured household questionnaire at the two irrigation schemes. The questionnaire captured the indicators of the farmers' livelihood status. The raw data were entered into the Statistical Package for Social Sciences (SPSS) software and analysed using descriptive statistics.

\section{Results and Discussion}

\subsection{General Characteristics of Irrigated-Plot Holders}

An analysis of the plot holder's sex revealed that there were more male plot-holders than female plot-holders for all irrigation systems except for those farmers using drip irrigation. Flood irrigation had most male plot-holders $(71.8 \%)$ while drip irrigation had the least (37.5\%), as shown in Table 1. Flood irrigation had the largest gap between male $(71.8 \%)$ and female $(28.2 \%)$ plot ownership. This is not the case however under drip irrigation which has more female (62.5\%) than male (37.5\%) plot holders. The Chi-square test results suggest that there is no association between sex of plot holder and irrigation system $(\mathrm{p}<0.05)$. 
Table 1 . Sex of plot holder by type of irrigation system, percent

\begin{tabular}{|c|c|c|c|c|}
\hline \multirow[t]{3}{*}{ Sex of plot holder } & \multicolumn{3}{|c|}{ Irrigation scheme and system } & \multirow[t]{3}{*}{ Total } \\
\hline & \multicolumn{2}{|c|}{ Hamamavhaire } & Mhende & \\
\hline & Sprinkler & Drip & Flood & \\
\hline Male & 68.8 & 37.5 & 71.8 & 67.1 \\
\hline Female & 31.2 & 62.5 & 28.2 & 32.9 \\
\hline Total & 100 & 100 & 100 & 100 \\
\hline$X^{2}$-value & 3.603 & & & \\
\hline
\end{tabular}

The results could be explained by the era in which the irrigation schemes were established in conjunction with the cultural and religious aspects of the society in which they are located. In most cases females tend to be sidelined in terms of land ownership due to cultural norms though they usually are the ones who provide most of the farm labour (Deribe, 2008). Both the sprinkler and flood irrigation systems at the two irrigation schemes were developed and commissioned in the year 1972. During this pre-independence (Note 3) era most development initiatives were not gender sensitive and women played a marginal role in society and could not own land. Consequently, the flood and sprinkler systems had a higher proportion of male plot holders. Contrary to this, the results also show that there were more female plot holders than male under the drip irrigation system section of Hamamavhaire irrigation scheme which was commissioned in 2001. This could be attributed to the widespread gender equality and women empowerment awareness campaigns and initiatives in development projects by the government of Zimbabwe in conjunction with NGOs during the past decade. This partly explains the dominance of female plot holders under the drip irrigation technology. Deribe (2008) in his study also came out with similar results. The participation of female-headed households at meetings and in irrigation scheme leadership was found to be very low. This suggests that policy intervention is required to encourage the participation of women in both farming activities and assume leadership roles in the Irrigation Management Committee (IMC).

A further comparison of the plot sizes owned by males versus females showed that the average plot sizes were almost the same within the irrigation systems. The analysis indicated that most farmers, who own irrigated plots, also own dry-land plots and small gardens. This could be explained by the cultural beliefs and values of the society which associates ownership of dry-land plots with prestige. The mean land holding data reflected that except for males using sprinkler irrigation system, the larger the average irrigated-plot size the smaller the average dry-land area owned as shown in Table 2. This trend can be explained by the more demanding nature of irrigated farming. Hence, farmers with larger irrigated plots prefer to put less effort on dry-land farming. This is supported by the correlation coefficient of -0.241 between average dry-land plot size and irrigated-plot size owned by the farmers, which suggests there is a negative relationship between the two variables.

Table 2. Mean land holding in hectares by irrigation system by sex of plot holder

\begin{tabular}{lllll}
\hline \multirow{2}{*}{ Sex of household head } & Type of plot & \multicolumn{3}{c}{ Irrigation scheme and system } \\
\cline { 3 - 5 } & & \multicolumn{2}{c}{ Hamamavhaire } & Mhende \\
\cline { 3 - 5 } Male & Sprinkler & Drip & Flood \\
\hline & Irrigation plot & 0.9 & 0.5 & 0.4 \\
& Garden & 0.0 & 0.0 & 0.0 \\
& Dry-land & 1.4 & 1.0 & 2.0 \\
\hline Female & Irrigation plot & 1.0 & 0.5 & 0.2 \\
& Garden & 0.0 & 0.0 & 0.0 \\
& Dry-land & 0.3 & 0.7 & 1.7 \\
\hline Correlation coefficient $=$ & -0.241 & \multicolumn{3}{l}{} \\
\hline
\end{tabular}


The occupation of the plot-holder and his/her family members is an important variable, as it hints on the availability of labour for various farm activities. One of the aims of irrigation development is to create employment for both the farmer and his/her surrounding community. The majority of the plot-holders across the irrigation systems were full-time farmers as shown in Table 3, [drip irrigation system (100\%), sprinkler irrigation (93.8\%) and flood irrigation system (74.4\%)]. The high frequency of full-time farmers in irrigation schemes was expected as irrigated farming demands more labour than dry-land farming. It is an activity which is more time consuming as it is not confined to the rainy season. The results of the Chi-square test seem to suggest that there was no association between the occupation of a plot-holder and irrigation system $(\mathrm{P}<0.05)$.

Table 3. Occupation of plot-holder by type of irrigation system, percent

\begin{tabular}{|c|c|c|c|}
\hline \multirow{3}{*}{ Occupation of household head } & \multicolumn{3}{|c|}{ Irrigation scheme and system } \\
\hline & \multicolumn{2}{|c|}{ Hamamavhaire } & \multirow{2}{*}{$\begin{array}{c}\text { Mhende } \\
\text { Flood }\end{array}$} \\
\hline & Sprinkler & Drip & \\
\hline Teacher & 0 & 0 & 2.6 \\
\hline Retiree & 0 & 0 & 5.1 \\
\hline Government Officer & 3.1 & 0 & 5.1 \\
\hline Farmer & 93.8 & 100 & 74.4 \\
\hline Other & 3.1 & 0 & 12.8 \\
\hline Total & 100 & 100 & 100 \\
\hline $\mathrm{X}^{2}$-value & 7.474 & & \\
\hline
\end{tabular}

The reliance of the plot-holder on farming as the major source of income is an important aspect of farm productivity as the farmer would devote most of his/her time to farm activities in order to maximize his/her returns. More than $74 \%$ of the farmers across all the irrigation systems were full-time farmers. This means that they rely mainly on farming as their source of livelihood. This confirms that the introduction of irrigation schemes in the area had contributed to employment creation for both the beneficiaries and non-beneficiaries as well. This is due to the high labour demand associated with irrigated farming as it is not confined to the rain season and crops are grown all year round. As a result, farmers using irrigation end up hiring-in labour to complement family labour. Labour is mostly hired-in for purposes such as land preparation, weeding and harvesting (as shown in Table 4).

Table 4. Mean labour required per hectare, mean labour hired-in per hectare, mean hours per week by farming activity by irrigation system

\begin{tabular}{|c|c|c|c|c|}
\hline \multirow{3}{*}{ Farming activity } & \multicolumn{3}{|c|}{ Irrigation scheme and system } & \multirow{3}{*}{ F-value } \\
\hline & \multicolumn{2}{|c|}{ Hamamavhaire } & \multirow{2}{*}{$\begin{array}{c}\text { Mhende } \\
\text { Flood }\end{array}$} & \\
\hline & Sprinkler & Drip & & \\
\hline \multirow{3}{*}{ Land preparation } & 7 & 7 & 4 & $15.013^{*}$ \\
\hline & (3) & $(0)$ & (0) & $29.066^{*}$ \\
\hline & 20 & 19 & 8 & $15.447 *$ \\
\hline \multirow{3}{*}{ Weeding } & 8 & 7 & 4 & $16.309^{*}$ \\
\hline & (5) & (1) & (0) & $30.500^{*}$ \\
\hline & 24 & 19 & 12 & $5.829^{*}$ \\
\hline \multirow{3}{*}{ Irrigating } & 1 & 2 & 2 & $4.615^{*}$ \\
\hline & (0) & (0) & (0) & \\
\hline & 17 & 12 & 3 & $33.154^{*}$ \\
\hline \multirow{3}{*}{ Harvesting } & 7 & 7 & 4 & $11.648^{*}$ \\
\hline & (4) & (1) & (1) & $29.869^{*}$ \\
\hline & 24 & 12 & 14 & $5.213^{*}$ \\
\hline
\end{tabular}

NB: *Statistical significance $\leq 0.05$, two tailed test for differences in means $\left(\mathrm{H}_{0}: \mu_{1}-\mu_{2}-\mu_{3}-\mu_{4}=0\right)$. 
Table 4 shows the results of labour analysis across the different irrigation technologies. For each farming activity, the mean labour required per hectare is shown in the first row. The mean hired-in labour per hectare for each farming activity is shown in parenthesis. The mean hours per week required for each activity are shown in bold. Farmers using both the sprinkler and drip irrigation systems required more labour per hectare for land preparation (7 people) and harvesting (7 people) activities. Farmers using the sprinkler system hired-in more labour for land preparation ( 3 people), weeding ( 5 people) and harvesting ( 4 people) when compared to those using flood and sprinkler systems. The hired labour complemented the family labour during times of peak labour demand.

The family labour in some instances tends to fall short of the overall labour demand. Consequently, the farmers end up hiring-in labour to complement the family labour for activities such as land preparation, weeding and harvesting. This creates employment for the people in the area surrounding the irrigation schemes. The results showed that farmers using the sprinkler irrigation system hired-in more labour than those under the other irrigation systems. The FAO (1999) also found out that employment opportunities in many regions increased after the introduction of irrigation systems in these areas. This was attributed to the additional labour requirements for planting and harvesting required for new land brought into production, for land that is being double cropped and for agricultural support industries such as processing firms.

The level of education of the plot-holders was also analyzed as it determines the type of decisions the farmers would make in relation to their farm operations. This also has repercussions on the ability of the farmers to perform proper agronomic practices. The results showed that the majority of the farmers had the basic primary and secondary level education valuable for their daily farming activities. The results also showed that most of the farmers did not have formal training in agriculture. Only $2.7 \%$ of farmers using the flood irrigation system had a master farmer training certificate, as shown in Table 5. The results of a Chi-square test suggested that there was an association between the level of education of plot holder and irrigation system $(\mathrm{p}<0.05)$.

Table 5. Type of system and level of education of plot holder, percent

\begin{tabular}{lcccc}
\hline Level of education & \multicolumn{3}{c}{ Irrigation scheme and system } \\
\cline { 2 - 5 } & \multicolumn{3}{c}{ Hamamavhaire } & Mhende \\
\cline { 2 - 5 } & Sprinkler & Drip & Flood \\
\hline Can read and write & 6.2 & 37.5 & 17.9 \\
& Primary level & 53.2 & 50.0 & 25.6 \\
Secondary level & 40.6 & 12.5 & 41.0 \\
Advanced level & 0 & 0 & 12.8 \\
Master farmer & 0 & 0 & 2.7 \\
Total & $\mathbf{1 0 0}$ & $\mathbf{1 0 0}$ & $\mathbf{1 0 0}$ \\
\hline $\mathrm{X}^{2}$-value $=15.823^{*}$ & & &
\end{tabular}

NB: * means significant at $5 \%$ level.

The majority of farmers across the three irrigation systems had attained both primary and secondary level education. This is important as the farmer's level of education has a direct impact on his/her ability to properly manage a given irrigation technology. The lack of formal training in agriculture for most farmers could pose a limitation to their productivity.

\subsection{Crop Production}

An analysis of crop production in terms of the area planted, average yield obtained and quantity of marketed surplus by irrigation system was also done (Table 6). The main crops grown by farmers across the irrigation systems were green maize, maize grain, wheat, sugar beans and groundnuts. Green maize and sugar beans were grown primarily as cash crops. Maize grain, groundnuts and wheat doubled as both cash and food crops. The main thrust of introducing irrigation technology in a farming system is to enhance food security and increase household income of the rural poor farmers. This therefore influences the choice of crops grown in the schemes as the aim is to meet these two goals. The mean differences of area under crop and the level of yield were significant for all crop enterprises except groundnuts $(\mathrm{P}<0.05)$. 
Table 6 shows that the average yield for maize grain $(7448 \mathrm{~kg} / \mathrm{ha})$, wheat $(5885 \mathrm{~kg} / \mathrm{ha})$, sugar beans $(2739.7$ $\mathrm{kgs} / \mathrm{ha})$ and groundnuts $(1060 \mathrm{~kg} / \mathrm{ha})$ was highest for farmers using the sprinkler irrigation when compared to mean yield of farmers using the other irrigation systems. This could be attributed to the way the sprinkler system simulates natural rainfall, which is more conducive for the production of most crops (Kandiah, 1997). Farmers using flood irrigation had the highest yields (2800 dozens/ha) and marketed surplus for green maize (1817 dozens/ha). The results suggest that farmers under the sprinkler category tend to be more food secure and self sustaining when compared to those using other irrigation systems.

Table 6. Mean area under cultivation, mean yield per hectare and mean marketed surplus per hectare by crop enterprise and irrigation system

\begin{tabular}{|c|c|c|c|c|c|}
\hline \multirow[t]{3}{*}{ Crop enterprise } & \multirow[t]{3}{*}{ Area/Yield/Quantity Sold } & \multicolumn{3}{|c|}{ Irrigation scheme and system } & \multirow{3}{*}{ F-values } \\
\hline & & \multicolumn{2}{|c|}{ Hamamavhaire } & \multirow{2}{*}{$\begin{array}{l}\text { Mhende } \\
\text { Flood }\end{array}$} & \\
\hline & & Sprinkler & Drip & & \\
\hline \multirow[t]{3}{*}{ Green maize } & Cultivated area (ha) & 0.4 & 0.3 & 0.1 & $24.100^{*}$ \\
\hline & Yield per hectare in dozens & 1405.5 & 531.3 & 2800.0 & $9.931^{*}$ \\
\hline & Marketed surplus(dozens/ha) & 1066.5 & 336.7 & 1817.0 & $15.471^{*}$ \\
\hline \multirow[t]{3}{*}{ Maize grain } & Cultivated area (ha) & 0.3 & 0.2 & 0.2 & $11.197^{*}$ \\
\hline & Yield per hectare in kg & 7448.0 & 2462.5 & 2961.5 & $37.125^{*}$ \\
\hline & Marketed surplus (kg/hectare) & 4307.3 & 1375.0 & 1275.5 & $26.956^{*}$ \\
\hline \multirow[t]{3}{*}{ Wheat } & Cultivated area (ha) & 0.3 & 0 & 0.1 & $15.794 *$ \\
\hline & Yield per hectare in kg & 5885.0 & $\mathbf{0}$ & 4351.0 & $28.587^{*}$ \\
\hline & Marketed surplus (kg/hectare) & 4010.3 & 0 & 2551.0 & $22.588^{*}$ \\
\hline \multirow[t]{3}{*}{ Sugar beans } & Cultivated area (ha) & 0.3 & 0.4 & 0.1 & $12.318^{*}$ \\
\hline & Yield per hectare in kg & 2739.7 & 945.3 & 1218.0 & $30.827^{*}$ \\
\hline & Marketed surplus (kg/hectare) & 2015.7 & 843.8 & 526.0 & $22.588^{*}$ \\
\hline \multirow[t]{3}{*}{ Ground nuts } & Cultivated area (ha) & 0.1 & 0.1 & 0.2 & 2.038 \\
\hline & Yield per hectare in kg & 1060.0 & 288.0 & 591.3 & 1.934 \\
\hline & Marketed surplus (kg/hectare) & 234.0 & 96.0 & 215.0 & 0.675 \\
\hline
\end{tabular}

NB: *Statistical significance $\leq 0.05$, two tailed test for differences in means $\left(\mathrm{H}_{0}: \mu_{1}-\mu_{2}-\mu_{3}-\mu_{4}=0\right)$.

The production of horticultural crops at the two irrigation schemes was limited and primarily done for subsistence purposes. This was attributed to the poor road networks which make it difficult to transport the perishable produce to the market. Hence, the cropping programs are skewed towards cereal and legume production. These results concur with those of Madyiwa and Zawe (2011) that smallholder irrigation schemes which are located far away from market centres tend to grow low value crops. The results also suggest that the farmers using sprinkler irrigation are significantly more efficient in the production of sugar beans, maize grain and wheat in terms of output per unit area and marketed surplus. This could be attributed to the high use of fertilizer, pesticides and hybrid seed per hectare by farmers using the sprinkler irrigation system (Table 7). Farmers using the flood irrigation system were found to be competent green maize producers.

Table 7 shows the results of the analysis of mean input usage per hectare for maize grain across the irrigation categories. Maize grain was chosen due its strategic position as a food crop. The aim was to get an insight on the input usage for the main food crop grown under irrigation. The F-test results show that there is no significant difference of the means for all inputs $(\mathrm{P}>0.05)$. Table 7 shows that the use of chemical fertilizers was prominent across the systems. The farmers using the sprinkler system dominate with an average of 294 kilograms of fertilizer bought per farmer for maize production. The use of pesticides and hybrid seeds was also common across the systems, with more farmers using sprinkler system. 
Table 7. Mean usage of fertilizer, pesticides, hired labour for maize grain production by irrigation system per hectare

\begin{tabular}{|c|c|c|c|c|c|}
\hline \multirow{3}{*}{ Crop name } & \multirow{3}{*}{ Input } & \multicolumn{3}{|c|}{ Irrigation scheme and system } & \multirow{3}{*}{ F-values } \\
\hline & & \multicolumn{2}{|c|}{ Hamamavhaire } & \multirow{2}{*}{\begin{tabular}{|c|} 
Mhende \\
Flood
\end{tabular}} & \\
\hline & & Sprinkler & Drip & & \\
\hline \multirow[t]{4}{*}{ Maize } & Seed $(\mathrm{kg} / \mathrm{ha})$ & 27 & 16 & 23 & 2.044 \\
\hline & Fertilizer (kg/ha) & 294 & 206 & 210 & 2.979 \\
\hline & Pesticide (kg/ha) & 1 & 1 & 1 & 3.166 \\
\hline & Hired labour (units/ha) & 2 & 0 & 0 & 0.139 \\
\hline
\end{tabular}

\subsection{Livestock Ownership}

The respondents were also asked questions on livestock ownership. Irrigated agriculture is labour intensive; hence, draught power is required in most cases. The major types of livestock kept by the farmers include: cattle, goats, sheep, donkeys and poultry. Livestock and crop production complement each other in various ways. The livestock produce manure for the crops and can be used as draught power. Livestock ownership is a variable, which can be used to reflect the wealth of the farmer.

Table 8 , shows the percentage of farmers owning livestock and mean livestock holding by type of irrigation system. The difference in means was statistically not significant for all livestock categories. Generally, most farmers across the irrigation systems own cattle. Farmers using sprinkler irrigation generally had the highest percent ownership of oxen (78.1\%), cows (93.8\%) and heifers and bulls (68.8\%) as compared to those using other irrigation systems. The total mean holding for cattle (oxen, cows, heifers and bulls) was 6 beasts per farmer for farmers using sprinkler or drip irrigation, which is significantly more than for those using flood irrigation. The most dominant small livestock owned by the farmers were goats with $78.1 \%$ of the farmers using sprinkler irrigation owning at least one goat. Generally, farmers using sprinkler irrigation invested more in livestock compared to farmers using other irrigation systems. This could be attributed to the high levels of marketed surplus per hectare for crops such as maize grain, wheat, sugar beans and groundnuts for farmers using sprinkler irrigation compared to those using the flood and drip systems.

Table 8. Percent farmers owning livestock and mean livestock holding by irrigation system

\begin{tabular}{|c|c|c|c|c|}
\hline \multirow{3}{*}{ Type of livestock } & \multicolumn{3}{|c|}{ Irrigation scheme and system } & \multirow{3}{*}{ F-value } \\
\hline & \multicolumn{2}{|c|}{ Hamamavhaire } & \multirow{2}{*}{$\begin{array}{c}\text { Mhende } \\
\text { Flood }\end{array}$} & \\
\hline & Sprinkler & Drip & & \\
\hline \multirow[t]{2}{*}{ Oxen } & 78.1 & 62.5 & 69.2 & \\
\hline & $(2)$ & $(2)$ & $(2)$ & 1.950 \\
\hline \multirow[t]{2}{*}{ Cow } & 93.8 & 100 & 64.1 & \\
\hline & (3) & (3) & $(2)$ & 1.816 \\
\hline \multirow[t]{2}{*}{ Heifer and Bulls } & 68.8 & 50 & 46.2 & \\
\hline & $(1)$ & (1) & $(1)$ & 0.980 \\
\hline \multirow[t]{2}{*}{ Sheep } & 0 & 12.5 & 15.4 & \\
\hline & $(0)$ & $(0)$ & (1) & 2.043 \\
\hline \multirow[t]{2}{*}{ Goats } & 78.1 & 50 & 61.5 & \\
\hline & (3) & (2) & $(2)$ & 1.040 \\
\hline \multirow[t]{2}{*}{ Donkeys } & 25 & 37.5 & 43.6 & \\
\hline & (1) & $(0)$ & $(1)$ & 0.671 \\
\hline \multirow[t]{2}{*}{ Poultry (chickens) } & 100 & 100 & 97.4 & \\
\hline & (15) & (12) & (12) & 0.679 \\
\hline
\end{tabular}




\subsection{Ownership of Farm Implements}

The level of farm mechanization of farmers across the irrigation systems was also analyzed. This is an important variable in determining agricultural performance. The farmers who had more farm implements were expected to have significantly high agricultural production. This is because the level of mechanization determines the scale of production and the level of efficiency. Table 9 shows the percentage of farmers owning farm implements and the average number of implements owned. The average number of implements owned is shown in parenthesis. The difference was significant for the garden fork, ox-cart and knapsack sprayer. Sprinkler system had a higher percent ownership for wheelbarrow (71.9\%), garden fork $(43.8 \%)$, ox-cart $(81.2 \%)$, watering can $(15.6 \%)$, knapsack sprayer $(65.6 \%)$ and sickle $(87.5 \%)$. The results seem to suggest a higher level of mechanisation in sprinkler compared to other systems. This observation could be attributed to the high levels of marketed surplus per hectare for crops such as maize grain, wheat, sugar beans and groundnuts for farmers using sprinkler irrigation.

Table 9. Percent farmers owning farm implements and mean implement holding by irrigation system

\begin{tabular}{|c|c|c|c|c|}
\hline \multirow[t]{3}{*}{ Type of Farm implement } & \multicolumn{3}{|c|}{ Irrigation scheme and system } & \multirow{3}{*}{ F-value } \\
\hline & \multicolumn{2}{|c|}{ Hamamavhaire } & \multirow{2}{*}{\begin{tabular}{|c|} 
Mhende \\
Flood
\end{tabular}} & \\
\hline & Sprinkler & Drip & & \\
\hline \multirow[t]{2}{*}{ Shovel } & 93.8 & 100 & 87.2 & \\
\hline & (2) & (3) & (2) & 0.462 \\
\hline \multirow[t]{2}{*}{ Wheelbarrow } & 71.9 & 50.0 & 59.0 & \\
\hline & (1) & (0) & (2) & 1.175 \\
\hline \multirow[t]{2}{*}{ Garden fork } & 43.8 & 75.0 & 20.5 & \\
\hline & (1) & (2) & $(0)$ & $4.149^{*}$ \\
\hline \multirow[t]{2}{*}{ Ox-cart } & 81.2 & 75.0 & 56.4 & \\
\hline & (1) & (1) & (1) & $3.256^{*}$ \\
\hline \multirow[t]{2}{*}{ Watering can } & 15.6 & 12.5 & 2.6 & \\
\hline & $(0)$ & $(0)$ & $(0)$ & 1.389 \\
\hline \multirow[t]{2}{*}{ Knapsack sprayer } & 65.6 & 50.0 & 12.8 & \\
\hline & (1) & $(0)$ & $(0)$ & $16.766^{*}$ \\
\hline \multirow[t]{2}{*}{ Sickle } & 87.5 & 87.5 & 82.1 & \\
\hline & $(2)$ & (2) & (2) & 0.070 \\
\hline \multirow[t]{2}{*}{ Tractor } & 0 & 0 & 2.6 & \\
\hline & (0) & (0) & (0) & 0.506 \\
\hline
\end{tabular}

NB: *Statistical significance $\leq 0.05$, two tailed test for differences in means $\left(\mathrm{H}_{0}: \mu_{1}-\mu_{2}-\mu_{3}-\mu_{4}=0\right)$.

\subsection{Asset Holding Across Systems}

Table 10 shows the percentage of farmers owning household assets and mean asset holding within the irrigation systems. The mean asset holding is shown in parenthesis. The difference in mean is statistically significant for functional mobile phone $(\mathrm{p}<0.05)$. Farmers using the sprinkler system had a significantly high percent ownership of a functional television (40.6\%), radio (65.6\%) and mobile phone (71.9\%). More than half of the farmers using sprinkler and flood systems own a functional radio and mobile phone. This means that they were fairly positioned in terms of information and communication, which is important in farming. 
Table 10. Percent farmers owning household assets and mean asset holding by irrigation system

\begin{tabular}{|c|c|c|c|c|}
\hline \multirow{3}{*}{ Asset Type } & \multicolumn{3}{|c|}{ Irrigation scheme and system } & \multirow{3}{*}{ F-value } \\
\hline & \multicolumn{2}{|c|}{ Hamamavhaire } & \multirow{2}{*}{\begin{tabular}{|c|} 
Mhende \\
Flood
\end{tabular}} & \\
\hline & Sprinkler & Drip & & \\
\hline \multirow{2}{*}{ House in town } & 9.4 & 0 & 5.1 & \\
\hline & (0) & (0) & (0) & 0.554 \\
\hline \multirow{2}{*}{ Functional television } & 40.6 & 0 & 28.2 & \\
\hline & $(0)$ & (0) & (0) & 2.373 \\
\hline \multirow{2}{*}{ Functional radio } & 65.6 & 37.5 & 53.8 & \\
\hline & $(1)$ & $(0)$ & (1) & 1.584 \\
\hline \multirow{2}{*}{ Functional mobile phone } & 71.9 & 37.5 & 56.4 & \\
\hline & (1) & (0) & (1) & $3.772 *$ \\
\hline \multirow{2}{*}{ Bicycle } & 46.9 & 37.5 & 48.7 & \\
\hline & $(1)$ & (1) & (1) & 0.030 \\
\hline
\end{tabular}

NB: *Statistical significance $\leq 0.05$, two tailed test for differences in means $\left(\mathrm{H}_{0}: \mu_{1}-\mu_{2}-\mu_{3}-\mu_{4}=0\right)$.

\subsection{Investments in Livestock, Farm Implements and Assets by Irrigation System}

Table 11 shows the responses of the farmers pertaining to whether they had invested in livestock, farm implements and/or household assets using their returns from irrigated crop production. The assumption made in the study was that irrigated farming improves the general livelihood of the rural poor. Improvement of the farmers' livelihoods was measured in terms of the farm implements, livestock and household assets, which were bought using returns from irrigated farming. Farmers using sprinkler irrigation indicated that they invested the most in farm implements (84.4\%) followed by livestock (59.4\%) and household assets (37.5\%). Farmers using drip irrigation indicated that they invested most in livestock (62.5\%) followed by farm implements $(50 \%)$ and household assets $(37.5 \%)$. Less than $50 \%$ of the farmers using flood irrigation had invested in farm implements, livestock and household assets. The results suggest that farmers using sprinkler irrigation had the highest improvement in livelihoods, followed by those using drip irrigation and flood irrigation respectively.

Table 11. Investment in livestock, farm implements and household assets by system, percent

\begin{tabular}{|c|c|c|c|c|}
\hline \multirow{3}{*}{ Type of investment } & \multirow{3}{*}{ Yes/No } & \multicolumn{3}{|c|}{ Irrigation scheme and system } \\
\hline & & \multicolumn{2}{|c|}{ Hamamavhaire } & \multirow{2}{*}{$\begin{array}{l}\text { Mhende } \\
\text { Flood }\end{array}$} \\
\hline & & Sprinkler & Drip & \\
\hline \multirow{2}{*}{ Farm implements } & Yes & 84.4 & 50.0 & 71.8 \\
\hline & No & 15.6 & 50.0 & 28.2 \\
\hline \multirow{2}{*}{ Livestock } & Yes & 59.4 & 62.5 & 12.8 \\
\hline & No & 40.6 & 37.5 & 87.2 \\
\hline \multirow{2}{*}{ Household assets } & Yes & 37.5 & 37.5 & 25.6 \\
\hline & No & 62.5 & 62.5 & 74.4 \\
\hline
\end{tabular}

\subsection{Environmental Impacts of Different Irrigation Systems}

The introduction of irrigated agriculture in a farming system brings both positive and negative environmental impacts. The magnitude of the negative environmental impact determines the sustainability of irrigated farming. The severe the externality, the less sustainable the intervention will be. The environmental impacts of the different irrigation technologies were captured in terms of the farmers' perception on the prevalence of soil loss, waterborne 
diseases and animal diseases. Table 12 shows the proportion of farmers who cited environmental problems associated with different irrigation systems.

The most prevalent problem across the irrigation systems was that of soil erosion. The results seem to suggest that more than $50 \%$ of the farmers using flood and drip irrigation systems acknowledged that soil erosion was a problem in their irrigation schemes. The extent of erosion was reported to be moderate by more than $50 \%$ of the respondents across all irrigation systems. The high prevalence of soil erosion reported by farmers using the drip irrigation is contrary to expectations. The system does not involve the overflow of water on the field. The high rate of soil erosion could be attributed to the poor agronomic practices of the farmers rather than the irrigation system.

Table 12. Environmental problems by irrigation system

\begin{tabular}{|c|c|c|c|c|}
\hline \multirow{2}{*}{ Type of problem } & \multirow{2}{*}{ Irrigation scheme } & \multirow{2}{*}{ Irrigation system } & \multicolumn{2}{|c|}{ Percentage of farmers } \\
\hline & & & Yes & No \\
\hline \multirow{3}{*}{ Soil erosion } & \multirow{2}{*}{ Hamamavhaire } & Sprinkler & 18.8 & 81.2 \\
\hline & & Drip & 62.5 & 37.5 \\
\hline & Mhende & Flood & 56.4 & 43.6 \\
\hline \multirow{3}{*}{ Water-borne diseases } & \multirow{2}{*}{ Hamamavhaire } & Sprinkler & 0 & 100 \\
\hline & & Drip & 0 & 100 \\
\hline & Mhende & Flood & 12.8 & 87.2 \\
\hline \multirow{3}{*}{ Animal disease } & \multirow{2}{*}{ Hamamavhaire } & Sprinkler & 0 & 100 \\
\hline & & Drip & 0 & 100 \\
\hline & Mhende & Flood & 0 & 100 \\
\hline
\end{tabular}

Waterborne diseases such as malaria, diarrhoea and bilharzias were rare across the irrigation systems. Of the farmers using flood irrigation only $12.8 \%$ indicated the existence of waterborne diseases. The results seem to suggest that sprinkler irrigation is more sustainable as farmers using the irrigation system experience less soil erosion, water-borne diseases and animal diseases. It is however, premature to conclude on environmental impacts by looking at prevalence only without taking note of the severity of the impacts. Table 13, summarizes the extent of soil erosion across the irrigation systems. The results show that more than $50 \%$ of the reported cases of soil erosion are moderate. Farmers using the sprinkler irrigation system reported the majority of severe cases of soil erosion (16.7\%), followed by the flood irrigation system (13.6\%). The high extent of soil erosion poses a major threat to the sustainability of these irrigation systems as more than $50 \%$ of respondents acknowledged that soil erosion was prevalent (Table 13). In theory, the drip irrigation system, however, is associated with less soil erosion. The study's findings confirm the results by FAO (1989) that the flood system is associated with a high prevalence of soil erosion.

Table 13. Extent of soil erosion by system, percent

\begin{tabular}{llcccc}
\hline \multirow{2}{*}{ Name of irrigation scheme } & \multirow{2}{*}{ Irrigation system } & \multicolumn{4}{c}{ Extent of soil erosion } \\
\cline { 3 - 6 } & & low & moderate & High & severe \\
\hline \multirow{2}{*}{ Hamamavhaire } & Sprinkler & 0 & 66.7 & 16.6 & 16.7 \\
& Drip & 0 & 80.0 & 20.0 & 0 \\
\hline Mhende & Flood & 4.5 & 72.7 & 9.2 & 13.6 \\
\hline
\end{tabular}

\section{Conclusion}

The study's findings show that the farmers using sprinkler irrigation were significantly better-off in terms of socio-economic indicators compared with those using the flood and drip irrigation systems. That is in terms of crop production, ownership of farm implements, investments made using irrigation income and level of education of plot holder. The differences in yield per hectare (for green maize, maize-grain, wheat and sugar-beans) were found 
to be significant $(\mathrm{P}<0.05)$ across the three irrigation systems. The study recommended that there is a need to provide the farmers with formal training in agriculture in order to enhance their agricultural performance.

\section{References}

Deribe, R. (2008). An Institutional Analysis of Water Management on Communal Irrigation Systems in Ethiopia: The case of Atsbi Wemberta, Tigray Region and Ada'a Woreda, Oromiya Region. MSc dissertation, Addis Ababa University.

FAO. (1989). Guidelines for designing and evaluating surface irrigation systems. FAO Irrigation and Drainage paper no. 45, Rome, Italy.

FAO. (1999). Zimbabwe: Smallholder Irrigation Development Project. Preparation Report, paper no. 99/030 $A D B-Z I M . \mathrm{FAO}$, Rome, Italy.

Gumbo, D. (2006). Working together to respond to climate change. Annex I Expert Group seminar in conjunction with the OECD Global Forum on Sustainable Development Zimbabwe country case study on domestic policy frameworks for adaptation in the water sector. WWF- Southern Africa.

Kandiah, A. (1997). Summary of findings of missions in selected countries in East and Southern Africa. In Irrigation technology transfer in support of food security. FAO sub-regional workshop, Harare, Zimbabwe. FAO, Rome.

Madyiwa, S., \& Zawe, C. (2011). Assessing experiences, outcomes and lessons learned from existing small-scale irrigation schemes in support of CAADP Pillar 1. International Water Management Institute, Pretoria, South Africa.

Makombe, G., \&. Sampath, R. K. (1998). An Economic Evaluation of Smallholder Irrigation Systems in Zimbabwe. International Journal of Water Resources Development, 14(1), 77-90. http://dx.doi.org/10.1080/07900629849510

Nhundu, K., Gwata, C., \& Mushunje, A. (2010). Impacts of Zimbabwe European Union micro-project programme in funding smallholder irrigation projects on food security and income levels: A case study of Mopane irrigation scheme in Zvishavane, Midlands province, Zimbabwe. African Journal of Agricultural Research, 5(14), 1759-1771.

Savva, P., \& Frenken, K. (2002). Planning, development, monitoring and evaluation of irrigated agriculture with farmer participation: FAO SARF, Harare. FAO, Rome.

\section{Notes}

Note 1. Hamamavhaire irrigation scheme is made up of two sections based on technology used that is the sprinkler system (drag hose) and the drip system.

Note 2. Mhende uses the flood system.

Note 3. Zimbabwe obtained its independence in 1980.

\section{Copyrights}

Copyright for this article is retained by the author(s), with first publication rights granted to the journal.

This is an open-access article distributed under the terms and conditions of the Creative Commons Attribution license (http://creativecommons.org/licenses/by/3.0/). 